\title{
Anthropogenic areas as incidental substitutes for original habitat
}

Alejandro Martínez-Abraín ${ }^{1,2}$ and Juan Jiménez ${ }^{3}$

${ }^{1}$ Evolutionary Biology Group, Facultad de Ciencias, Universidade da Coruña, Campus da Zapateira s/n, 15071 A Coruña, Spain, email a.abrain@udc.es

${ }^{2}$ Population Ecology Group, Mediterranean Institute of Advanced Studies (CSIC-UIB), C/Miquel Marquès 21, 07190 Esporles, Mallorca, Spain.

${ }^{3}$ Servicio de Vida Silvestre. Consellería de Infraestructuras, Territorio y Medio Ambiente. Generalitat Valenciana. C/ Castán Tobeñas, 77, 46018 Valencia, Spain

Running head: Incidental habitat substitutes

Keywords: substitution habitats, adopted species, functional equivalence, new concepts, human-modified systems, conservation, resilience 


\begin{abstract}
One speaks of ecological substitutes when an introduced species performs, to some extent, the ecosystem function of an extirpated native species. We suggest that a similar case exists for habitats. Species evolve within ecosystems, but habitats can be destroyed or modified by natural and human-made causes. Sometimes habitat alteration forces animals to move to or remain in a suboptimal habitat type. In that case, the habitat is considered a refuge, and the species is called a refugee. Typically refugee species have lower population growth rates than in their original habitats. Human action may lead to the unintended generation of artificial or semiartificial habitat types that functionally resemble the essential features of the original habitat and thus allow a population growth rate of the same magnitude or higher than in the original habitat. We call such areas substitution habitats and define them as human-made habitats within the focal species range that by chance are partial substitutes for the species' original habitat. We call species occupying a substitution habitat adopted species. These are two new terms for conservation biology.. Examples of substitution habitats are dams for European otters, wheat and rice fields for many steppeland and aquatic birds, and urban areas for storks, falcons or swifts. Although substitution habitats can bring about increased resilience against the agents of global change, the conservation of original habitat types remains a conservation priority.
\end{abstract}




\section{Introduction}

The ecological literature is rich in cases in which the functional role played by native extinct or extirpated species has been taken over, to some extent, by non-native species. For example, introduced birds in Hawaii disperse the seeds of common understory native plants that, in turn, may facilitate the native forest and introduced birds compensate for extinct native dispersers on the Bonin Islands of Japan (Martínez-Abraín \& Oro 2013). Also, after the extinction of endemic lizards following the arrival of the first human settlers, introduced Pine Martens (Martes martes) became the main disperser of the native shrub Ceneorum tricoccon on Mallorca Island (Alcover 2008; Valenzuela \& Alcover 2013). Those nonnativenon-native species are, at least partially, carrying out the role of extinct or extirpated native species; that is, they are ecological substitutes or functional equivalents of them. A similar situation occurs when considering the substitutive role of some domesticated animals (i.e. cattle, horses, and even sheep and goats when in low densities) that, to some extent, replace the functional role of extinct mammalian herbivores from the late Pleistocene in that they create and maintain mosaic-type landscapes that maximize biological diversity (Blondel 2006; De Gabriel et al. 2011; Rivera-Sánchez et al. 2015).

We suggest that a parallel exists relative to habitats. Following modification, through natural or anthropogenic forces, of the habitat in which an animal species evolved a species can remain in the modified habitat in suboptimal refuges; move to another modified habitat that is at least partially equivalent to its original habitat (i.e., substitute habitat); or move to an area of original natural habitat, if some remains. The first scenario applies to so-called refugees species (Kerley et al. 2011; Bocherens et al. 2015). It has been suggested that the European bison (Bison bonasus), presently a forest dweller, is actually a refugee species in European forests because it evolved in open grasslands, but only populations that secondarily 
occupied forests survived human persecution during the late Pleistocene and Holocene. A second example is that of Mediterranean monk seals (Monachus monachus). These marine mammals now breed mostly inside cliff caves along coastlines where large sand beaches are present. The only functional colony of the species occurs in the Cabo Blanco Peninsula in Mauritania. However, biological and ecological characteristics of this species (e.g., the dark color of pups may be an adaption that protects them from direct sunlight and pup mortality inside caves is higher than mortality on beaches [Martínez-Jauregui et al. 2012]) have led to the the suggestion that these seals are actually refugees in littoral caves. In fact, as soon as they move back to open beaches their breeding success increases substantially (González \& M'Barek 2004). A third example is Iberian brown bears (Ursus arctos), which used to be distributed across mountain ranges and flat plains throughout the Iberian Peninsula centuries ago. Due to heavy human persecution since the early Middle Ages, now they occur only as refugee species in valleys with steep slopes in the northern Sierras (such as Cordillera Cantábrica and the Pyrenees), suboptimal habitat for a plantigrade. Finally, the European wolf (Canis lupus), originally an inhabitant of open landscapes, is now mainly a refugee in forested mountains, again due to human persecution.

The scenario, in which a species moves out of one modified habitat to another that is a good equivalent of the original corresponds to our substitution habitat idea. We define substitution habitats as those human-made habitats located within the range of a species that, by chance, are partial substitutes for a species' original habitat. We refer to these species as adopted species. Refugee species have lower population growth rates than adopted species. Substitution habitats are occupied by species that actively select these sites despite the availability of refuge habitats. Some refugee species, which we have used as study models for years, have recently became adopted species when they moved to substitution habitats. 


\section{Gulls as refugee and adopted species}

We suggest elsewhere that Audouin's Gull (Larus audouinii) most likely evolved in dune fields and coastal marshes associated with river deltas (Martínez-Abraín et al. 2003). We based this hypothesis on the fact that they change breeding-colony sites despite successful breeding in previous years. Other factors supporting the evolution of this species in unstable continental coastal environments, rather than on islets, include the lack of a fossil record of gulls on small Mediterranean islets (Alcover et al. 1992) and rapid growth of Audouin's Gull colonies once they colonize such ecosystems (e.g., Oro \& Ruxton 2001). However, human development of coastlines in the recent past (i.e., massive beach tourism development during the 20th century) precipitated their use of small land-bridge and oceanic archipelagos across the Mediterranean Sea. The first colonies found in the western Mediterranean during the 1970s were indeed on small uninhabited volcanic islets, so the species was wrongly considered a small-island specialist. Consequently, it was used as a flagship species to promote the conservation of these small archipelagos, a positive output associated with a misconception. Now evidence shows that these islets were a refuge habitat and that Audouin's Gull was a refugee species in those small islets because their nomadic behavior is better suited to the low stability of continental river deltas (Parejo et al. 2006; Oro et al.

2011). This is probably the case as well for other large ground-nesting gull species of Europe, such as Yellow-legged Gull (L. michahellis), Caspian Gull (L. cachinnans), Herring Gulls (Larus argentatus) and Black-backed Gull (L. fuscus), that modify the vegetation substrate of the islets where they breed with their nitrogen-rich feces (Vidal et al. 1998) to the point of making it unhospitable for near-term future breeding. Ground-nesting gulls do not face that problem in their evolutionary habitat types because the high salt content in the soils (i.e., arenosols in beaches and dune fields of river deltas) prevents the development of ruderal 
vegetation. Nitrogen is provided by gull feces, but freshwater is retained by the salts in the soil. Hence, the rapid growth of nitrophilous vegetation (such as Lavatera species) is prevented. The only island-nesting gull species for which such an illogical ecological process does not occur is the Kittiwake (Rissa tridactyla), which nests, and hence defecates, directly on islet cliffs rather than on the ground. Kittiwakes are most likely the only legitimate (native rather than refugee) islet gull in Europe.

The successful growth of Audouin's Gull colonies in human-made salinas (saltpans) and ports (including small marinas and large harbors) along the western Mediterranean coast suggests that these continental habitats act as substitution habitats, rather than as refuge habitats, for the species. Hence, in salinas the species behaves as an adopted species, rather than a refugee species, because these areas seem to be good substitutes of their original coastal continental habitats.Both are flat, open, have sparse vegetation, and are close to food sources.). We used the classical equation for discrete exponential population growth $\left(N(t)=N(0) \lambda^{t}\right.$ to compare the rate of change in the number of breeding pairs of Audouin's Gull in Spain when the species bred in refuge habitats ( $\lambda$ or annual geometric growth rate in small islets $=0.96 ; 95 \%$ CI $0.95-0.98)$, the rate of change in substitution habitats $(\lambda=1.12 ; 95 \%$ CI 1.05-1.20), and the rate of change in areas of relatively original habitat $(\lambda=0.92 ; 95 \%$ CI $0.87-0.99)$. Gulls breeding in substitution habitats had higher $\lambda$ values ( $12 \%$ mean annual increase) than gulls breeding in refuge habitats (4\% mean annual decrease in islets) and higher values of $\lambda$ than gulls breeding in relatively original habitat, such as beaches and dune fields in continental river deltas, where gulls showed an $8 \%$ mean annual decrease. Hence, in this case, substitution habitats attracted more breeding birds than original and refuge habitats. Most likely substitution habitats contained basic food resources similar to original habitats, but probably the former had fewer predators due their proximity to humans (scarecrow effect 
[Leighton et al 2010]). (make this next part a separate sentence and rephrase; it is unclear what property you are referring to, lack of predators or proximity to humans; avoid redundancy, however) Low predations risk in part defines substitution habitats because they are human-made habitats and typically have high human occupancy, that works as a shield against predation.

\section{European otters as refugee and adopted species}

European otters have been considered for decades as almost exclusive inhabitants of unpolluted river heads (e.g., Mason \& MacDonald 1986). However, otter populations are expanding in Europe from river heads to the middle and lower river reaches (e.g., LópezMartín \& Jiménez 2008). This spread suggests that most likely otters occurred in river heads during the last decades not because they specifically selected upper parts of rivers, but rather as a consequence of human pressure in the more populated and polluted low-elevation areas, even though these areas are more productive and have greater quantities of preferred prey of otters than river heads (Remonti et al. 2009). Thus, rivers with otters only in their oligotrophic heads should be considered refuge habitats, and otters in these areas should be considered refugee species. Indeed otters have higher reproductive success in the middle stretches of rivers than in higher stretches that acted as refuges (Ruíz-Olmo et al. 2011).

Recent human alteration of rivers sometimes gives rise unintentionally to new otter habitat (frequently in the middle part of the rivers) that mimics the ecological characteristics of the lower part of rivers (i.e., calm water and high densities and richness of prey species than river heads). This is the case with freshwater reservoirs and dams, where otter prey usually, but not always, consists of introduced non-native species such as pumpkinseed fish (Lepomis gibosus) or American crayfish (Procambarus clarkii) (Pedroso \& Santos-Reis 2006, Sales-Luís et al. 2007). We suggest that otters in artificial dams could be considered adopted 7
Comentario [A1]: It is just one property, not two. Human-made habitats are full of humans and because of that fact do not have many predators. It is also called the shield effects in addition to the scarecrow effect

Comentario [A2]: The meaning of this sentence has changed. What I meant is that otters are recovering precisely in the lower reaches of rivers and that this is an experimental proof of the fact that they were not voluntary inhabitants of river heads. They were forced to live up there.

Comentario [A3]: Although makes no sense here. A lower breeding success shows that river heads were only refuges. 
species and that reservoirs act as substitution habitats for them. This idea can be traced to Ruíz-Olmo and Jiménez's (2008) suggestion that reservoirs can have some "substitutive role" for more natural otter habitats.

\section{Cereal fields as substitution habitats}

Although rice cultivation introduces a strong seasonal component to the environment, many rice fields provide abundant food for breeding and wintering water birds, including ducks, herons, gulls, and terns. Rice paddies provide an excellent ecological alternative to the original freshwater marshes (Elphick 2000). Hence, rice fields could be considered substitution habitats and species using them adopted species. For example breeding gullbilled terns (Sterna nilotoca) get most of their food to feed their chicks from rice fields in eastern Spain (Dies et al. 2005). The importance of rice fields for water birds was highlighted by Tablado et al. (2010). They found that the positive effect of this human-made habitat on predatory birds is often mediated by the presence of non-native prey such as the red swamp crayfish (Procambarus clarkii).

A similar situation exits with dry cereal cultivation in former natural steppes or open areas deforested long ago. Many animal species (notably steppe birds) find these agroecosystems good substitutes for their former natural biotopes. For example, most (81\%) Montagu's harriers (Circus pygargus) breeding in Spain do so in cereal fields (Arroyo \& García 2007). Smaller, but still substantial, percentages of hen harriers (C. cyaneus) and marsh harriers (C. aeruginosus) also make use of cereal fields for breeding in Spain (Molina \& Martínez 2008). Hence many former steppe birds are now adopted species in cereal fields that act as substitution habitats. We believe, as do others (Wolff et al. 2002; Suárez-Seoane et al. 2002 ) that preservation of these agricultural practices helps in the conservation of a large number of bird species that are not abundant in central and northern Europe, such as those of 8 
the family Pteroclididae. Cereal fields act as substitution habitats despite cultivation schedules and practices can create some conservation conflicts. For example, the wheat harvest coincides with harrier breeding, especially when the harvest is early due to high temperature. Also, the chemical treatment of crops or the use of chemically-treated seed can be sources of pollution.

\section{Urban areas as substitution habitats}

Villages, towns, and cities often provide habitat substitutes for birds. Cliff-nesting birds such as swifts (Apus sp.) and house martins (Delichon urbica) find building façades or chimneys substitute for breeding habitat . Sand Martins (Riparia riparia) and Honey Eaters (Merops apiaster) use abandoned sand quarries for breeding. Peregrine falcons (Falco peregrinus) have colonized cities and now breed successfully on the top of skyscrapers. They prey on city birds, many of which, use urban parks as substitutes for their original forest habitats. Cavitynesting birds use holes in walls as a substitute for holes in old-growth trees and rock outcrops. Tree-dwelling bats live in urban parks, occupying tree-bark crevices (e.g. PopaLisseanu et al. 2009). White Storks (Ciconia ciconia) breed on top of roofs or antenna instead of on top of big trees. Urban fauna may also benefit from the scarecrow effect and from the higher mean temperatures associated with urban areas. Indeed, some species, such as house martins, now so rarely breed in natural environments that substitution in this case has been almost complete. Urban areas can also lead to ecological traps (e.g. Robertson \& Hutto 2006) but not always. Urbanized areas (together with agricultural fields) are older examples of substitution habitats than reservoirs and salinas. However, both are relatively recent at the time scale at which the evolution of focal species takes place in their original habitats.

\section{Conclusions}


First, substitution habitats differ widely in their level of human influence. Focusing on our examples, urban areas, marinas, and ports represent highly modified systems relative to an original habitat type, whereas dry and wet cereal fields and salinas are seminatural systems. In all cases, however, these habitats have been human made and were not intended to promote biological diversity.

Second, knowing whether species actually are native, refugee, or adopted species to a habitat is a basic piece of information needed for successful conservation. Managers may promote restoration of the original habitat if species are refugees, or they could increase the resemblance of substitution habitats to original habitat in the case of adopted species. The distinction implies the necessity of identifying the habitat in which the focal species originally evolved, a task that is not always straightforward, and of a deep knowledge of the species biology and ecology, which can only be acquired after long periods of study. Such knowledge can be derived from the fossil record and phylogenetic trees (providing cues about changes in paleoranges); the careful study of the anatomy, physiology, and behavior of the focal species; and the estimation of fitness components at individual (fecundity, survival, recruitment) and population (population growth rates) levels. Occupation of refuge and substitution habitats may often be coupled with changes in behavior and diet of focal species. This is especially so in substitution habitats because human-made environments contain an altered species composition (i.e. typically a simplified community structure that reduces competition pressure and allows the manifestation of suboptimal foraging strategies that are part of the plastic but cryptic tool kit of many species) and abundant, predictable food sources of human origin (Oro et al. 2013). Substitution habitats may increase the probability of preserving wildlife in a rapidly changing world, and the concept of substitution habitats coincides with the aims of reconciliation ecology developed by Rosenzweig (2003). 
However Rosenzweig's (2003) “reconciled habitats" should not be equated with our substitution habitats because the former are built on purpose by humans in urbanized landscapes to foster biological diversity, whereas the latter are unintentional by-products of human activity. Rosenzweig's concept of "happy accidents" fits our idea better. However, happy accident is more inclusive because it integrates any human activity that ends up having an unexpected positive effect on wildlife, not only the generation of new habitats that provide the main functional role of original habitats by chance. For example, the unexpected effect of the construction of an airport increasing Montagu's harrier distribution range and the positive effect of windfarms on Griffon vulture (Gyps fulvus) expansion(Oro et al. 2012) would also be happy accidents that are not associated with the creation of new habitat.

It needs to be kept in mind that modified habitats can be substitutive only of some system functions and only for some species; they are not substitutive of the original community as a whole. Hence, they will always be suboptimal from a global conservation perspective. Although substitution habitats can increase individual species resilience, when faced with the agents of global change (especially habitat loss and fragmentation), preserving original habitat types remains the best global conservation option. Of course not all humanmade habitats are substitutive. An industrial park built on top of a former steppe would not provide substitute habitat for steppe birds, and a greenhouse field built on a former wetland would not have any value for marsh water birds. From a conservation perspective it would be good news if most human-made habitat was substitutive of some original habitat type.

\section{Acknowledgments}

We are grateful to D. Oro who provided data on Audouin's Gull counts per habitat in the Ebro Delta colony and kindly commented on a couple of initial drafts of the document. 


\section{Literature cited}

Alcover, JA. 2008. The first Mallorcans: Prehistoric colonization in the western Mediterranean. Journal of World Prehistory 21:19-84.

Alcover JA, Florit F, Mourer-Chauviré C, Weesie P. 1992. The avifaunas of the isolated Mediterranean islands during the Middle and Late Pleistocene. Natural History Museum of Los Angeles County Science Series 36: 273-283.

Arroyo B, García J. 2007. El aguilucho cenizo y el aguilucho pálido en España. Población en 2006 y método de censo. SEO/BirdLife. Madrid

Blondel, J. 2006. The "design” of Mediterranean landscapes: A millennial story of humans and ecological systems during the historic period. Human Ecology 34: 713-729.

Bocherens H, Hofman-Kaminska E, Drucker DG, Schmölcke U, Kowalczyk R. 2015. European bison as a refugee species? Evidence from isotopic data on early Holocene bison and other large herbivores in Northern Europe. PLoS ONE 10 (e01150090). DOI:10.1371/journal.pone.0115090.

DeGabriel JL., Albon SD, Fielding DA, Riach DJ, Westaway S, Irvine RJ 2011. The presence of sheep leads to increases in plant diversity and reductions in the impact of deer on heather. Journal of Applied Ecology 48: 1269-1277.

Dies JI, Marín J, Pérez C. 2005. Diet of nesting gull-billed tern in Eastern Spain. Waterbirds 28: 106-109.

Elphick, CS. 2000. Functional equivalency between rice fields and seminatural wetland habitats. Conservation Biology 14: 181-191.

Con formato: Inglés (Reino Unido) Con formato: Inglés (Reino Unido) Con formato: Español (alfab. internacional) 
González LM, M’Barek HO. 2004. Un recorrido por la historia natural del Guerguerat y la península de Cabo Blanco. Dirección General para la Biodiversidad. Ministerio de Medio Ambiente. Madrid.

Kerley G, Kowalczyk R, Cromsigt M. 2011. Conservation implications of the refugee species concept and the European bison: king of the forest or refugee in a marginal habitat?

Ecography 35: 519-529.

Leighton PA, Horrocks J, Kramer DL. 2010. Conservation and the scarecrow effects: Can human activity benefit threatened species by displacing predators? Biological Conservation 143:2156-2163.

López-Martín JM, Jiménez J, editors. 2008. La nutria en España. Veinte años de seguimiento de un mamífero amenazado. SECEM. Málaga.

Martínez-Abraín A, Oro D. 2013. Preventing the development of dogmatic approaches in conservation biology: a review. Biological Conservation 159:539-547.

Martínez-Abraín A, Oro D, Forero MG, Conesa D. 2003. Modelling temporal and spatial colony-site dynamics in a long-lived seabird. Population Ecology 45: 133-139.

Martínez-Jauregui M, Tavecchia G, Cedenilla MA, Coulson T, Fernández de Larrinoa P, Muñoz M. 2012. Population resilience of the Mediterranean Monk Seal Monachus monachus at Cabo Blanco Peninsula. Marine Ecology Progress Series 461:273-281.

Mason CF, MacDonald SM. 1986. Otters: ecology and conservation. Cambridge University Press.

Molina B, Martínez F. 2008. El aguilucho lagunero en España. Población en 2006 y método de censo. SEO/BirdLife. Madrid. 
Oro D, Ruxton GD. 2001. The formation and growth of seabird colonies: Audouin's Gull as a case study. Journal of Animal Ecology 70: 527-535.

Oro D, Tavecchia G, Genovart M. 2011. Comparing demographic parameters of philopatric and immigrant individuals in a long-lived bird adapted to unstable habitats. Oecologia 165: $935-945$.

Oro D, Jiménez J, Curcó A. 2012. Some clouds have a silver lining: Paradoxes of anthropogenic perturbations from study cases on long-lived social birds. PLOS ONE 7:e42753.

Oro D, Genovart M, Tavecchia G, Fowler MS, Martínez-Abraín A. 2013. Ecological and evolutionary implications of food subsidies from humans. Ecology Letters 16: 1501-1514.

Parejo D, Oro D, Danchin E. 2006. Testing habitat copying in breeding habitat selection in a species adapted to variable environments. Ibis 148: 146-154.

Pedroso NM, Santos-Reis M. 2006. Summer diet of Eurasian otters in large dams of Southern Portugal. Hystrix Italian Journal of Mammalogy 17: 117-128.

Popa-Lisseanu AG, Bontadina F, Ibáñez C. 2009. Giant noctule bats face conflicting constraints between roosting and foraging in a fragmented and heterogeneous landscape. Journal of Zoology 278: 126-133.

Remonti L, Balestrieri A, Prigioni C. 2009. Altitudinal gradient of Eurasian otter (Lutra lutra) food niche in Mediterranean habitats. Canadian Journal of Zoology 87: 285-291.

Rivera-Sánchez L, Roldán J, Baraza E, Filella J. 2015. Comparative study of trophic Con formato: Inglés (Reino Unido) behaviour and herd structure in wild and feral goats living in a Mediterranean island: management implications. Applied Animal Behaviour Science: 165:81-87. 
Robertson BA, Hutto RL. 2006. A framework for understanding ecological traps and an evaluation of existing evidence. Ecology 87:1075-1085.

Rosenzweig M. 2003. Win-win Ecology, How the Earth's species can survive in the midst of human enterprise. Oxford, UK: Oxford University Press.

Ruíz-Olmo J, Jiménez J. 2008. Ecología de la nutria en los ambientes mediterráneos de la Península Ibérica. Pages: 305-343 in López-Martín JM, Jiménez J, editors. La nutria en España. Veinte años de seguimiento de un mamífero amenazado. SECEM, Málaga.

Ruíz-Olmo J, Batet A, Mañas F, Martínez-Vidal R. 2011. Factors affecting otter (Lutra lutra) abundance and breeding success in freshwater habitats of the northeastern Iberian Peninsula. European Journal of Wildlife Research 57:827-842.

Sales-Luís T, Pedroso NM, Santos-Reis M. 2007. Prey availability and diet of the Eurasian otter (Lutra lutra) on a large reservoir and associated tributaries. Canadian Journal of Zoology 85: 1125-1135.

Suárez-Seoane S, Osborne PE, Alonso JC. 2002. Large-scale habitat selection by agricultural steppe birds in Spain: identifying species-habitat responses using generalized additive models. Journal of Applied Ecology 39: 755-771.

¿Tablado Z, Tella JL, Sánchez-Zapata JA, Hiraldo F. 2010. The paradox of long-term positive Con formato: Inglés (Reino Unido) effects of a Northamerican crayfish on a European community of predators. Conservation Biology 24: 1230-1238.

Valenzuela A, Alcover JA. 2013. Radiocarbon evidence for a prehistoric deliberate translocation: the weasel (Mustela nivalis) of Mallorca. Biological Invasions 15:717-722. 
.Vidal E, Medail F, Tatoni T. 1998. Is the yellow-legged gull a superabundant bird species in the Mediterranean? Impact on flora and fauna, conservation measures and research priorities. Biodiversity and Conservation 7: 1013-1026.

Wolff A, Paul, JP, Martin JL, Bretagnolle V. 2002. The benefits of extensive agriculture to birds: the case of the little bustard. Journal of Applied Ecology 38: 963-975. 